\title{
Analisis finansial usaha peternakan ayam petelur CV Makmur Jaya Lumajang Jawa Timur
}

\section{Layer financial analysis at CV Makmur Jaya Lumajang East Java}

\author{
Niswatin Hasanah1, Ferrinda Melynia1, Suluh Nusantoro1, dan Suci \\ Wulandari ${ }^{1}$ \\ ${ }^{1}$ Program Studi Produksi Ternak, Jurusan Peternakan, Politeknik Negeri Jember, Jl. \\ Mastrip 164, Jember 68101 \\ *Email Koresponden: niswatin hasanah@polije.ac.id
}

\begin{abstract}
Abstrak. Studi kasus ini dilakukan di CV Makmur Jaya Lumajang. Studi kasus ini bertujuan untuk mengetahui kelayakan usaha pada CV Makmur Jaya Lumajang ditinjau dari segi analisis finansial. Studi ini dilaksanakan pada tanggal 10 Agustus sampai dengan 13 September 2020 di peternakan ayam ras petelur CV Makmur Jaya Lumajang. Pada studi kasus menggunakan bahan yaitu ayam ras petelur strain Hysex Brown sebanyak 30.000 ekor. Parameter pengamatan menggunakan analisis penerimaan atas biaya, dan analisis titik impas. Hasil pengamatan ini menunjukkan bahwa hasil penerimaan sebesar Rp9.223.780.000,00 dan angka pendapatan sebesar Rp1.603.955.000,00. Sehingga dengan hasil tersebut dapat menentukan analisis penerimaan atas biaya 1,210 . Hasil pada analisis BEP harga memperoleh hasil Rp14.615,845 dan pada BEP produksi $448.225 \mathrm{~kg}$. Dengan demikian peternakan ayam ras petelur CV Makmur Jaya Lumajang usahanya memperoleh keuntungan dan layak untuk dijalankan.
\end{abstract}

Kata kunci: biaya produksi, profit, ayam petelur, r/c ratio, break even point

\begin{abstract}
This case study was conducted in CV Makmur Jaya Lumajang. This case study aims to determine the location of the business on CV. Makmur Jaya Lumajang in terms of financial analysis. This study was conducted from August 10 to September 13, 2020, at the CV. Makmur Jaya Lumajang. In the case study, 30000 chickens were used, namely the Hysex Brown strain laying hens. Observation parameters using revenue analysis on costs, and analysis of the break-even point. The results of this observation indicate that the revenue is $R p$ 9,223,780,000.00 and the income is $R p$ $1,603,955,000.00$. So, with these results can determine the acceptance of the cost of 1,210 . The results of the BEP analysis, the cost of production is Rp14,615,845 and in the BEP, the production is $448,225 \mathrm{~kg}$. Thus, laying chicken CV Makmur Jaya Lumajang is profitable and feasible to run.
\end{abstract}

Keywords: production costs, profit, laying hens, r/c ratio, break even point

\section{PENDAHULUAN}

Kesadaran dari arti penting peningkatan gizi dalam kehidupan harus terus diimbangi mengingat akan perkembangan jumlah penduduk yang selalu meningkat dari tahun ke tahun. Seiring dengan meningkatnya jumlah penduduk maka kebutuhan akan pangan juga mengalami peningkatan, antara lain kebutuhan pangan hewani dan nabati. Permintaan pasar akan kebutuhan pangan hewani semakin meningkat seiring dengan kemajuan teknologi dan peningkatan pendidikan dalam masyarakat. Pengembangan peternakan sangat penting untuk 
mendukung terpenuhinya permintaan pasar akan kebutuhan pangan hewani. Salah satu usaha dalam peternakan untuk memenuhi permintaan pasar akan kebutuhan pangan hewani adalah usaha peternakan ayam petelur. Kegiatan pengembangan usaha peternakan ayam petelur ini adalah salah satu cara dalam rangka untuk memenuhi kebutuhan telur dalam masyarakat. Menurut Direktorat Jenderal Peternakan dan Kesehatan Hewan (2015) pada tahun 2014 sampai 2015 populasi pada ayam petelur dan produksi telur yang dihasilkan meningkat sebesar $3,24 \%$.

Usaha peternakan ayam ras petelur di CV Makmur Jaya Lumajang merupakan suatu bukti dari investasi yang ditanamkan agar memberikan nilai ekonomi yang berkelanjutan kepada pemilik dan orang lain. Untuk menjaga kelangsungan usaha tersebut, perlu waktu perencanaan dan gambaran usaha untuk kedepannya sehingga memerlukan adanya peningkatan volume pada ayam petelur. Arifin (2004) menyatakan bahwa ketika kita menjalankan suatu investasi banyak prinsip yang harus dipertimbangkan, misalnya investasi dalam saham , tabungan, maupun membuka usaha. Namun kendala yang dihadapi bagi peternakan ayam adalah biaya relatif tinggi, sedangkan modal yang dimiliki terbatas, dan kondisi dari perekonomian tidak stabil yang dapat menyebabkan harga dari sarana produksi menjadi tinggi sehingga membutuhkan modal sangat besar.

Peternakan CV Makmur Jaya ini merupakan suatu usaha peternakan secara mandiri tidak sebagai peserta kemitraan. Dengan demikian peternak bermasalah dengan pasar dan pada penyediaan sarana produksi, yang dapat menimbulkan kurangnya pengetahuan peternak sehingga peternak kurang memperhatikan biaya produksi yang dikeluarkan. Dengan kata lain usaha peternakan tersebut dapat bertahan jika memperoleh keuntungan lebih besar daripada biaya yang dikeluarkan. Berdasarkan beberapa uraian diatas, maka akan dilakukan suatu studi kasus pada peternakan ayam petelur di CV Makmur Jaya Lumajang mengenai kelayakan usaha secara finansial. Studi kasus ini dilakukan untuk mengetahui kondisi keuangan dari usaha peternakan tersebut dengan menghitung menggunakan biaya investasi perusahaan, dan biayabiaya yang dikeluarkan selama proses produksi berlangsung sehingga dapat menentukan atau mengalami titik impas.

\section{MATERI DAN METODE}

Studi kasus ini dilakukan di peternakan ayam ras petelur CV Makmur Jaya Lumajang, waktu studi kasus dimulai pada tanggal 10 Agustus sampai 13 September 2020. Alat yang digunakan dalam studi kasus ini meliputi buku, bolpoin, kamera, kalkulator, dan alat pelindung diri seperti sarung tangan dan masker. Bahan yang digunakan adalah ayam petelur strain Hysex Brown sebanyak 30.000 ekor.

Adapun metode kegiatan yang dilakukan dengan cara pengambilan data yaitu :

a. Observasi

Metode kegiatan yang dilakukan untuk memperoleh data di peternakan ayam ras petelur CV Makmur Jaya yaitu pengumpulan data dengan cara pengamatan langsung di lapangan guna untuk memperoleh fakta-fakta atau data-data yang diperlukan.

b. Dokumentasi

Metode kegiatan yang kedua untuk memperoleh data di peternakan ayam ras petelur CV Makmur Jaya dengan dokumentasi, yaitu suatu metode untuk memperoleh data atau informasi mengenai hal-hal yang ada dengan cara melihat kembali laporan-laporan tertulis baik berupa angka maupun keterangan. Dan dokumentasi merupakan metode pengambilan data berupa gambar yang berhubungan dengan objek pada suatu perusahaan.

c. Wawancara

Metode kegiatan yang terakhir yaitu dengan wawancara, suatu metode yang dilakukan atau digunakan dalam memperoleh data secara langsung melalui tatap muka dan tanya jawab (mengajukan pertanyaan secara langsung) pada pihak perusahaan. 
Hasanah et al.

ANIMPRO: Conference of Applied Animal Science Proceeding Series

\section{Parameter Pengamatan}

Revenue cost ratio $(R / C)$

Revenue cost ratio $(R / C)$ adalah perbandingan antara penerimaan penjualan dengan biaya yang dikeluarkan selama proses produksi (Simanungkalit, 2008). Analisis $\mathrm{R} / \mathrm{C}$ adalah alat analisis yang digunakan untuk mengetahui biaya dari suatu penerimaan produksi pada suatu perusahaan. Rumus perhitungan R/C sebagai berikut:

$$
\text { Perhitungan } \mathrm{R} / \mathrm{C}=\frac{\text { Total Penerimaan }(\mathrm{Rp})}{\text { Total Biaya }(\mathrm{Rp})}
$$

Kriteria:

Jika $\mathrm{R} / \mathrm{C}<1$ maka usaha pada CV. Makmur Jaya Lumajang dikatakan rugi.

Jika R/C > 1 maka usaha pada CV. Makmur Jaya Lumajang dikatakan untung

Jika $\mathrm{R} / \mathrm{C}=1$ maka usaha pada CV. Makmur Jaya Lumajang dikatakan impas (tidak untung dan tidak rugi)

\section{Break even point (BEP)}

Analisis BEP memberikan informasi mengenai jumlah volume penjualan, dimana pada peternakan ayam ras petelur CV Makmur Jaya berada pada kondisi tidak mengalami kerugian dan keuntungan atau dalam arti kata lain yaitu impas. Break even point merupakan titik pertemuan antara biaya dan penerimaan, namun BEP dibagi menjadi dua yaitu BEP produksi dan BEP harga (Simanungkalit, 2008). BEP produksi digunakan untuk mengetahui berapa penjualan yang impas sedangkan pada BEP harga digunakan untuk mengetahui berapa jumlah penerimaan yang harus dicapai pada peternakan ayam ras petelur CV Makmur Jaya Lumajang. Analisis BEP adalah titik batas minimum volume penjualan yang mencapai keadaan tidak untung dan tidak rugi. Rumus perhitungan BEP adalah sebagai berikut:

Rumus perhitungan dari BEP adalah sebagai berikut:

$\begin{array}{ll}\text { BEP harga } & =\frac{\text { Total Biaya }(\mathrm{Rp})}{\text { Total Produksi }(\mathrm{Kg})} \\ \text { BEP produksi }= & \text { Total Biaya }(\mathrm{Rp}) \\ \text { Harga Penjualan }(\mathrm{Rp})\end{array}$

Kriteria :

Jika $B E P>0$ maka usaha pada CV. Makmur Jaya Lumajang dikatakan untung

Jika $B E P=0$ maka usaha pada CV. Makmur Jaya dikatakan impas, dalam artian impas yaitu perusahaan ayam ras petelur tersebut tidak untung dan tidak rugi

Jika $B E P<0$ maka usaha pada $C V$. Makmur Jaya tersebut dikatakan rugi

\section{HASIL DAN PEMBAHASAN}

\section{Analisis Rugi Laba}

Tabel analisis rugi laba merupakan sejumlah uang yang keluar dan masuk dari kegiatan yang dilakukan pada peternakan ayam ras petelur CV Makmur Jaya Lumajang dalam waktu satu tahun. Biaya produksi terdiri dari biaya tetap dan biaya tidak tetap. Biaya tetap merupakan biaya yang tidak berubah-ubah sedangkan pada biaya variabel tersebut dipengaruhi oleh besar kecilnya suatu produksi sehingga menyebabkan biaya tersebut berubah-ubah sebanding dengan volume kegiatan. Penerimaan merupakan semua hasil penjualan dari hasil produksi yang dilakukan pada peternakan ayam ras petelur CV Makmur Jaya yaitu penjualan telur dan ayam afkir. Sedangkan pendapatan adalah pengurangan dari penerimaan yang dihasilkan dan total dari biaya produksi pada peternakan ayam ras petelur CV Makmur Jaya. Melihat suatu efisiensi dari usaha yang dijalankan dapat menggunakan perbandingan antara penerimaan dan pengeluaran atau biasa disebut rasio penerimaan atas biaya. Break even point (BEP) digunakan untuk menentukan batas minimum volume penjualan dimana pada peternakan ayam ras petelur CV Makmur Jaya tidak untung dan tidak rugi dalam artian impas. 
Satuan ternak (ST) adalah suatu ukuran yang digunakan untuk menghubungkan berat badan (BB) ternak dengan jumlah pakan yang telah dimakan. Pada ternak unggas khususnya pada ayam terdapat tiga penggolongan berdasarkan umur yaitu pada umur kurang dari setengah tahun, umur setengah tahun, dan pada umur lebih dari setengah tahun. Pada CV Makmur Jaya tergolong ayam dewasa yaitu lebih dari setengah tahun dan satuan ternak (ST) adalah sebesar 1,00 ST (setiap 100 ekor ternak ayam). Jadi untuk perhitungan Satuan Ternak (ST) dari 30.000 populasi pada CV Makmur Jaya adalah sebesar 300,00 ST. Gambaran mengenai analisis rugi laba dan perhitungan satuan ternak (ST) dapat dilihat pada tabel dibawah ini.

Tabel 1. Analisis Rugi Laba

\begin{tabular}{|c|c|c|c|c|c|}
\hline Nomor & Uraian & Satuan & Nilai (Rp) & $\begin{array}{c}\text { Satuan } \\
\text { Ternak (ST) }\end{array}$ & $\begin{array}{l}30.000 \\
\text { ekor }\end{array}$ \\
\hline \multirow[t]{14}{*}{$A$} & Biaya & & & & \\
\hline & a. Biaya tetap & & & & \\
\hline & $\begin{array}{l}\text { Pembelian tanah } \\
\text { Penyusutan: }\end{array}$ & $\mathrm{Ha}$ & 2.000.000.000 & 6.666 .667 & $66.666,667$ \\
\hline & Penyusutan kandang & & 80.000 .000 & 266.667 & 2.667 \\
\hline & Penyusutan peralatan & & 2.500 .000 & 8.333 & 83 \\
\hline & Total biaya tetap & & 2.082.500.000 & 6.941 .667 & 69.417 \\
\hline & Pembelian DOC & Ekor & 390.000 .000 & 1.300 .000 & 13.000 \\
\hline & Biaya pakan & $\mathrm{Kg}$ & 4.312 .350 .000 & 14.374 .500 & 143.745 \\
\hline & Biaya vaksin & & 49.875 .000 & 166.250 & 1.663 \\
\hline & Biaya vitamin dan obat & & 17.100 .000 & 57.000 & 570 \\
\hline & Biaya tenaga kerja & Orang & 756.000 .000 & 2.520 .000 & 25.200 \\
\hline & Biaya listrik & Watt & 12.000 .000 & 40.000 & 400 \\
\hline & Total biaya tidak tetap & & 5.537 .325 .000 & 18.457 .750 & 184.578 \\
\hline & Biaya Total Produksi & & 7.619 .825 .000 & 25.399.417 & 253.994 \\
\hline \multirow[t]{4}{*}{ B } & Penerimaan & & & & \\
\hline & Telur ayam & $\mathrm{Kg}$ & 8.862.780.000 & 29.542 .600 & 295.426 \\
\hline & Ayam afkir & Ekor & 361.000 .000 & 1.203 .333 & 12.033 \\
\hline & Total penerimaan & & 9.223 .780 .000 & 30.745 .933 & 307.459 \\
\hline C & Pendapatan (B-A) & & 1.603 .955 .000 & 5.346 .517 & 53,465 \\
\hline D & $\mathrm{R} / \mathrm{C}$ rasio $(\mathrm{A} / \mathrm{B})$ & & 1,210 & 0,004 & 0,00004 \\
\hline \multirow[t]{3}{*}{$E$} & BEP & & & & \\
\hline & BEP harga & $\mathrm{Rp}$ & $14.615,845$ & 48,719 & 0,487 \\
\hline & BEP produksi & $\mathrm{Kg}$ & 448.225 & 1.494 & 14,941 \\
\hline
\end{tabular}

Sumber: Data diolah 2020 CV Makmur Jaya Lumajang

\section{Biaya Tetap (Fixed Cost)}

Biaya tetap merupakan biaya yang dikeluarkan oleh peternakan ayam ras petelur CV Makmur Jaya yang mempunyai sifat yaitu tetap, artinya dalam pengeluaran biaya tersebut tidak tergantung dari besar kecilnya suatu produksi (Abidin, 2002). Biaya investasi peternakan ayam ras petelur di CV Makmur Jaya yaitu pembelian tanah sebesar Rp2.000.000.000,00. Sedangkan pada biaya penyusutan yaitu sebesar Rp82.500.000,00. Untuk biaya penyusutan tersebut merupakan biaya pembuatan kandang sebesar Rp800.000.000,00 dan biaya peralatan sebesar Rp25.000.000,00. Kedua biaya tersebut terdapat penyusutan yaitu pada 10 tahun usia ekonomis. Total biaya tetap yang dikeluarkan pada CV Makmur Jaya adalah sebesar Rp2.082.500.000,00. Pada CV Makmur Jaya tergolong ayam dewasa yaitu lebih dari setengah tahun dan satuan ternak (ST) adalah sebesar 1,00 ST (setiap 100 ekor ternak ayam). Jadi untuk perhitungan satuan ternak (ST) dari 30.000 populasi pada CV Makmur Jaya adalah sebesar 300,00 ST. Gambaran mengenai rincian pada biaya tetap terdapat pada tabel dibawah ini. 
Hasanah et al.

ANIMPRO: Conference of Applied Animal Science Proceeding Series

Tabel 2. Biaya Tetap

\begin{tabular}{lllll}
\hline Uraian & Biaya $(\mathrm{Rp})$ & $\begin{array}{l}\text { Per 12 bulan } \\
(\mathrm{Rp})\end{array}$ & $\begin{array}{l}\text { Satuan Ternak } \\
(\mathrm{ST})\end{array}$ & 30.000 ekor \\
\hline Pembelian tanah & 2.000 .000 .000 & 2.000 .000 .000 & 6.666 .667 & $66.666,667$ \\
Penyusutan kandang & 80.000 .000 & 80.000 .000 & 266.667 & 2.667 \\
Penyusutan peralatan & 2.500 .000 & 2.500 .000 & 8.333 & 83 \\
\hline Total & & 2.082 .500 .000 & 6.941 .667 & 69.417 \\
\hline
\end{tabular}

Sumber: Data diolah 2020 CV Makmur Jaya Lumajang

Biaya Tidak Tetap (Variabel Cost)

Biaya pembelian DOC

CV Makmur Jaya menjalankan usahanya dalam beternak ayam petelur, dengan cara melakukan pembelian DOC berumur 1 hari dari perusahaan tempat penjualan DOC. Day old chicken (DOC) 1 boks berisi 100 ekor dan per boks dibeli dengan harga sebesar Rp13.000. Total jumlah ayam yang dipelihara di peternakan ayam ras petelur CV. Makmur Jaya sebanyak 30.000 ekor. Pada CV Makmur Jaya tergolong ayam dewasa yaitu lebih dari setengah tahun dan satuan ternak (ST) adalah sebesar 1,00 ST (setiap 100 ekor ternak ayam). Jadi untuk perhitungan Satuan Ternak (ST) dari 30.000 populasi pada CV Makmur Jaya adalah sebesar 300,00 ST. Besarnya biaya yang dikeluarkan oleh CV Makmur Jaya untuk pembelian DOC dapat dilihat lebih rinci pada tabel dibawah ini.

Tabel 3. Biaya Pembelian DOC

\begin{tabular}{cccccc}
\hline Uraian & Jumlah & Harga $(\mathrm{Rp})$ & Total & $\begin{array}{c}\text { Satuan Ternak } \\
(\mathrm{ST})\end{array}$ & $\begin{array}{r}30.000 \\
\text { ekor }\end{array}$ \\
\hline Pembelian DOC & 30.000 & 13.000 & 390.000 .000 & 1.300 .000 & 13.000 \\
\hline
\end{tabular}

Sumber: Data diolah 2020 CV. Makmur Jaya Lumajang

\section{Biaya pakan}

Peternakan ayam ras petelur CV Makmur Jaya dalam memberikan pakan ayam ras petelur disesuaikan dengan umur ayam. Kebutuhan per ekor pada ayam berbeda-beda karena tergantung pada umur ayam tersebut. Pakan 1 untuk ayam periode starter pada umur 0 sampai 5 minggu dengan kebutuhan untuk 30.000 ekor ternak yaitu sebesar $600 \mathrm{~kg}$ dengan perkilo harganya adalah sebesar Rp3.500,00, sehingga untuk biaya sekali makan sebesar Rp2.100.000,00 dan untuk sampai 5 minggu membutuhkan biaya sebesar Rp73.500.000,00. Pakan 2 untuk ayam periode grower pada umur 6 sampai 12 minggu dengan kebutuhan untuk 30.000 ekor ternak yaitu sebesar $1500 \mathrm{~kg}$ dengan perkilo harganya adalah sebesar Rp3.500,00, sehingga untuk biaya sekali makan sebesar Rp5.250.000,00 dan totalnya yaitu membutuhkan biaya sebesar Rp257.250.000,00. Pakan 3 untuk ayam periode pre layer pada umur 13-18 minggu dengan kebutuhan untuk 30.000 ekor ternak yaitu sebesar $3.300 \mathrm{~kg}$ dengan perkilo harganya adalah sebesar Rp4.000,00, sehingga untuk biaya sekali makan sebesar Rp13.200.000,00 dan totalnya yaitu membutuhkan biaya sebesar Rp554.400.000,00. Pakan 4 untuk ayam periode layer pada umur 18 sampai 52 minggu (karena perhitungan analisis usaha dalam setahun masa produksi) dengan kebutuhan untuk 30.000 ekor ternak yaitu sebesar 3.600 $\mathrm{kg}$ dengan perkilo harganya adalah sebesar Rp4.000,00, sehingga untuk biaya sekali makan sebesar Rp14.400.000,00 dan totalnya yaitu membutuhkan biaya sebesar Rp3.427.200.000,00. Jadi total untuk biaya pakan pada peternakan ayam ras petelur CV Makmur Jaya adalah sebesar Rp4.312.350.000,00. Pada CV Makmur Jaya tergolong ayam dewasa yaitu lebih dari setengah tahun dan satuan ternak (ST) adalah sebesar 1,00 ST (setiap 100 ekor ternak ayam). Jadi untuk perhitungan satuan ternak (ST) dari 30.000 populasi pada CV Makmur Jaya adalah sebesar 300,00 ST. Gambaran mengenai biaya pakan pada peternakan ayam ras petelur CV Makmur Jaya pada tabel dibawah ini. 
Hasanah et al.

ANIMPRO: Conference of Applied Animal Science Proceeding Series

Tabel 4. Biaya Pakan

\begin{tabular}{ccccccc}
$\begin{array}{c}\text { Jenis } \\
\text { Pakan }\end{array}$ & $\begin{array}{c}\text { Kebutuhan } \\
\text { per 30.000 } \\
\text { ekor }(\mathrm{Kg})\end{array}$ & $\begin{array}{c}\text { Harga } \\
\text { per Kg } \\
(\mathrm{Rp})\end{array}$ & $\begin{array}{c}\text { Biaya sekali } \\
\text { makan (Rp) }\end{array}$ & $\begin{array}{c}\text { Biaya per 12 } \\
\text { bulan (Rp) }\end{array}$ & $\begin{array}{c}\text { Satuan } \\
\text { Ternak (ST) }\end{array}$ & $\begin{array}{c}30.000 \\
\text { ekor }\end{array}$ \\
\hline Pakan 1 & 600 & 3.500 & 2.100 .000 & 73.500 .000 & 245.000 & 2.450 \\
Pakan 2 & 1.500 & 3.500 & 5.250 .000 & 257.250 .000 & 857.500 & 8.575 \\
Pakan 3 & 3.300 & 4.000 & 13.200 .000 & 554.400 .000 & 1.848 .000 & 18.480 \\
Pakan 4 & 3.600 & 4.000 & 14.400 .000 & 3.427 .200 .000 & 11.424 .000 & 114.240 \\
\hline Total & & & & 4.312 .350 .000 & 14.374 .500 & 143.745 \\
\hline
\end{tabular}

Sumber: Data diolah 2020 CV Makmur Jaya Lumajang

\section{Biaya vaksin}

Peternakan ayam ras petelur CV Makmur Jaya penyegahan penyakit sangat penting karena merupakan salah satu tindakan yang harus diterapkan oleh peternak, karena pencegahan penyakit jauh lebih baik dilakukan dibandingkan harus mengobati ayam yang sudah sakit. Vaksinasi bertujuan untuk mencegah ternak dari berbagai macam penyakit yang disebabkan oleh bakteri, virus, jamur dan parasit. Program vaksin yang ada pada peternakan ayam ras petelur CV. Makmur Jaya meliputi cacar, EDS, AI, corysa, ND lasota, bronkitis, dan gumboro.

Biaya untuk program vaksinasi cacar sebesar Rp56.000,00 untuk kapasitas 1.000 ekor ternak jika untuk kapasitas 30.000 ekor ternak dikalikan 30 maka hasilnya sebesar Rp1.680.000,00. Biaya untuk program vaksinasi egg drop syndrome sebesar Rp552.000,00 untuk kapasitas 1.000 ekor ternak jika untuk kapasitas 30.000 ekor ternak dikalikan 30 maka hasilnya adalah sebesar Rp16.560.000,00. Biaya untuk program vaksinasi avian influenza sebesar Rp415.000,00 untuk kapasitas 1.000 ekor ternak jika untuk kapasitas 30.000 ekor ternak dikalikan 30 maka hasilnya adalah sebesar Rp12.450.000,00. Biaya untuk program vaksinasi corysa sebesar Rp325.000,00 untuk kapasitas 1.000 ekor ternak jika untuk kapasitas 30.000 ekor ternak dikalikan 30 maka hasilnya adalah sebesar Rp10.560.000,00. Biaya untuk program vaksinasi ND lasota sebesar Rp115.000,00 untuk kapasitas 1.000 ekor ternak jika untuk kapasitas 30.000 ekor ternak dikalikan 30 maka hasilnya adalah sebesar Rp3.450.000.000,00. Biaya untuk program vaksinasi bronkitis sebesar Rp65.000,00 untuk kapasitas 1.000 ekor ternak jika untuk kapasitas 30.000 ekor ternak dikalikan 30 maka hasilnya adalah sebesar Rp1.950.000.000,00. Biaya untuk program vaksinasi gumboro sebesar Rp215.000,00 untuk kapasitas 1.000 ekor ternak jika untuk kapasitas 30.000 ekor ternak dikalikan 30 maka hasilnya adalah sebesar Rp3.225.000.000,00. Jadi total untuk biaya vaksinasi pada peternakan ayam ras petelur CV. Makmur Jaya mengeluarkan biaya sebesar Rp49.875.000. Pada CV. Makmur Jaya tergolong ayam dewasa yaitu lebih dari setengah tahun dan Satuan Ternak (ST) adalah sebesar 1,00 ST (setiap 100 ekor ternak ayam). Jadi untuk perhitungan Satuan Ternak (ST) dari 30.000 populasi pada CV. Makmur Jaya adalah sebesar 300,00 ST. Rincian biaya vaksinasi disajikan pada Tabel 5 ..

Tabel 5. Biaya Vaksin

\begin{tabular}{lccccc}
\hline Program Vaksin & $\begin{array}{c}\text { Harga satuan } \\
(\mathrm{Rp})\end{array}$ & $\begin{array}{c}\text { Kapasitas } \\
\text { ayam (ekor) }\end{array}$ & $\begin{array}{c}\text { Jumlah biaya } \\
30.000 \text { ekor (Rp) }\end{array}$ & $\begin{array}{c}\text { Satuan } \\
\text { Ternak (ST) }\end{array}$ & $\begin{array}{c}30.000 \\
\text { ekor }\end{array}$ \\
\hline Cacar & 56.000 & 1.000 & 1.680 .000 & 5.600 & 56 \\
Egg drop syndrome & 552.000 & 1.000 & 16.560 .000 & 55.200 & 552 \\
Avian influenza & 415.000 & 1.000 & 12.450 .000 & 41.500 & 415 \\
Corysa & 352.000 & 1.000 & 10.560 .000 & 35,200 & 352 \\
ND Lasota & 115.000 & 1.000 & 3.450 .000 & 11.500 & 115 \\
Bronkitis & 65.000 & 1.000 & 1.950 .000 & 6.500 & 65 \\
Gumboro & 215.000 & 2.000 & 3.225 .000 & 10.750 & 108 \\
\hline \multicolumn{2}{l}{} & & 49.875 .000 & 166.250 & 1.663 \\
\hline
\end{tabular}

Sumber: Data diolah 2020 CV Makmur Jaya Lumajang 
Hasanah et al.

ANIMPRO: Conference of Applied Animal Science Proceeding Series

\section{Biaya Vitamin dan Obat}

Ternak sangat memerlukan vitamin dan obat-obatan agar kesehatan ternak tidak mudah terserang berbagai macam penyakit. Peternakan ayam ras petelur CV Makmur Jaya Lumajang menggunakan Rhodivit dan Enro Forte. Harga Rhodivit yaitu Rp750.000,00 setiap 1 kg, dan pada satu kandang hanya diberikan sebanyak 10 gram. Sehingga untuk kebutuhan Rhodivit diperlukan sebanyak 8,4 kg untuk memenuhi kebutuhan 30.000 ternak. Jadi untuk Rhodivit dengan harga Rp750.000,00 dikali dengan kebutuhan ternak 30.000 sehingga biaya yang dikeluarkan sebesar Rp6.300.000,00.

Satu botol pada Enro Forte berisi 1 liter untuk kapasitas 1000 ekor ternak yang dapat digunakan selama 3 hari berturut-turut. Sehingga untuk kebutuhan 30.000 ternak mengeluarkan biaya sebesar Rp10.800.000,00. Jadi pada penggunaan Enro Forte memerlukan 30 botol untuk 30.000 ekor ternak yang ada pada perusahaan ayam ras petelur CV Makmur Jaya Lumajang. Pada CV. Makmur Jaya tergolong ayam dewasa yaitu lebih dari setengah tahun dan Satuan Ternak (ST) adalah sebesar 1,00 ST (setiap 100 ekor ternak ayam). Jadi untuk perhitungan Satuan Ternak (ST) dari 30.000 populasi pada CV. Makmur Jaya adalah sebesar 300,00 ST. Tabel dibawah ini merupakan rincian biaya vitamin dan obat yang dikeluarkan pada CV. Makmur Jaya Lumajang.

Tabel 6. Biaya Vitamin dan Obat

\begin{tabular}{lcccccc}
\hline $\begin{array}{c}\text { Merk vitamin } \\
\text { dan obat }\end{array}$ & Harga (Rp) & Kapasitas & Kebutuhan & Jumlah (Rp) & $\begin{array}{c}\text { Satuan } \\
\text { Ternak (ST) }\end{array}$ & $\begin{array}{c}30.000 \\
\text { ekor }\end{array}$ \\
\hline Rhodivit & 750.000 & $1 \mathrm{~kg}$ & $8.4 \mathrm{~kg}$ & 6.300 .000 & 21.000 & 210 \\
Enro Forte & 360.000 & 1.000 ekor & 30 buah & 10.800 .000 & 36.000 & 360 \\
\hline \multicolumn{7}{c}{ Total } \\
\hline
\end{tabular}

Sumber: Data diolah 2020 CV Makmur Jaya Lumajang

Biaya tenaga kerja

Usaha peternakan ayam ras petelur CV Makmur Jaya menggunakan 35 orang tenaga kerja yang masing-masing tenaga kerja mempunyai tugas dan bagian berbeda. Pada satu kandang dikelola oleh satu orang yang menjaga dan mengurus kandang tersebut lalu pada siang hari setelah memanen telur melakukan penyetoran dan penimbangan telur dibagian utara kandang. Biaya tenaga kerja per bulan yang diberikan sesuai dengan Upah Minimum Regional (UMR) kabupaten Lumajang yaitu Rp1.800.000,00. Total biaya yang dikeluarkan untuk upah tenaga kerja setiap bulan sebesar Rp63.000.000,00 dan dalam satu tahun sebesar Rp756.000.000,00. Usaha peternakan CV Makmur Jaya tergolong ayam dewasa yaitu lebih dari setengah tahun dan satuan ternak (ST) adalah sebesar 1,00 ST (setiap 100 ekor ternak ayam). Jadi untuk perhitungan Satuan Ternak (ST) dari 30.000 populasi pada CV Makmur Jaya adalah sebesar 300,00 ST. Gambaran mengenai sistem upah tenaga kerja yang dikeluarkan oleh CV Makmur Jaya dapat dilihat pada tabel dibawah ini.

Tabel 7. Biaya Tenaga Kerja

\begin{tabular}{cccccc}
\hline $\begin{array}{c}\text { Jumlah } \\
\text { tenaga kerja }\end{array}$ & Upah (Rp) & Total upah (Rp) & $\begin{array}{c}\text { Jumlah Per 12 } \\
\text { bulan (Rp) }\end{array}$ & $\begin{array}{c}\text { Satuan } \\
\text { Ternak (ST) }\end{array}$ & 30.000 ekor \\
\hline 35 Orang & 1.800 .000 & 63.000 .000 & 756.000 .000 & 2.520 .000 & 25.200 \\
\hline Total & & 756.000 .000 & 2.520 .000 & 25.200 \\
\hline Sumber: Data diolah 2020 CV. Makmur Jaya Lumajang
\end{tabular}

\section{Biaya listrik}

Pemakaian listrik di peternakan ayam ras petelur di CV Makmur Jaya digunakan untuk keperluan penerangan yaitu lampu pada jalan depan perusahaan dan jalan utama. Kandang tidak diberi lampu untuk penerangan pada malam hari, jadi penerangan pada kandang adalah alami dari sinar matahari pada pagi hari saja. Keperluan listrik lainnya adalah menggunakan air untuk keperluan air minum pada ternak dan untuk kebutuhan tenaga kerja. Peternakan ayam ras 
petelur di CV Makmur Jaya mengeluarkan biaya sebesar Rp1.000.000,00 dalam satu bulan dan dalam satu periode mengeluarkan biaya sebesar Rp12.000.000,00. Pada CV. Makmur Jaya tergolong ayam dewasa yaitu lebih dari setengah tahun dan satuan ternak (ST) adalah sebesar 1,00 ST (setiap 100 ekor ternak ayam). Jadi untuk perhitungan satuan ternak (ST) dari 30.000 populasi pada CV Makmur Jaya adalah sebesar 300,00 ST. Gambaran mengenai pemakaian biaya listrik pada CV Makmur Jaya pada dilihat pada tabel dibawah ini.

Tabel 8. Biaya Listrik

\begin{tabular}{cccc}
\hline Listrik per bulan (Rp) & Per 12 bulan (Rp) & Satuan Ternak (ST) & 30.000 ekor \\
\hline 1.000 .000 & 12.000 .000 & 40.000 & 400 \\
\hline Total & 12.000 .000 & 40.000 & 400 \\
\hline
\end{tabular}

Sumber: Data diolah 2020 CV Makmur Jaya Lumajang

\section{Total biaya variabel}

Total biaya variabel merupakan penjumlahan dari komponen biaya variabel yang dikeluarkan oleh peternakan ayam ras petelur CV Makmur Jaya. Pada total biaya variabel ini memperhatikan jumlah ternak yang tersedia, karena semakin banyak ternak yang dipelihara maka semakin banyak biaya yang dikeluarkan. Komponen biaya yang dikeluarkan terdiri atas biaya pembelian DOC, biaya pakan, biaya listrik, biaya tenaga kerja, biaya vaksin, dan biaya vitamin dan obat. Pada CV Makmur Jaya tergolong ayam dewasa yaitu lebih dari setengah tahun dan satuan ternak (ST) adalah sebesar 1,00 ST (setiap 100 ekor ternak ayam). Jadi untuk perhitungan satuan ternak (ST) dari 30.000 populasi pada CV Makmur Jaya adalah sebesar 300,00 ST. Di bawah ini merupakan rincian total dari seluruh biaya variabel yang dikeluarkan oleh perusahaan ayam ras petelur CV Makmur Jaya Lumajang.

Tabel 9. Total Biaya Variabel

\begin{tabular}{lccc}
\hline \multicolumn{1}{c}{ Uraian } & Jumlah & Satuan Ternak (ST) & 30.000 ekor \\
\hline Pembelian DOC & 390.000 .000 & 1.300 .000 & 13.000 \\
Biaya Pakan & 4.312 .350 .000 & 14.374 .500 & 143.745 \\
Biaya Vaksin & 49.875 .000 & 166.250 & 1.663 \\
Biaya Vitamin dan Obat & 17.100 .000 & 57.000 & 570 \\
Biaya Tenaga Kerja & 756.000 .000 & 2.520 .000 & 25.200 \\
Biaya Listrik & 12.000 .000 & 40.000 & 400 \\
\hline \multicolumn{1}{c}{ Total } & 5.537 .325 .000 & 18.457 .750 & 184.578 \\
\hline
\end{tabular}

Sumber: Data diolah 2020 CV Makmur Jaya Lumajang

Berdasarkan tabel diatas, menunjukkan bahwa total biaya variabel yang dikeluarkan oleh peternakan ayam ras petelur CV. Makmur Jaya adalah sebesar Rp5.537.325.000,00. Biaya variabel terbesar yang dikeluarkan oleh peternakan ayam ras petelur CV. Makmur Jaya adalah biaya pakan yaitu sebesar Rp4.312.350.000,00. Urutan kedua adalah biaya tenaga kerja yaitu sebesar Rp756.000.000,00. Urutan ketiga adalah biaya pembelian DOC yaitu sebesar Rp390.000.000,00. Urutan keempat adalah biaya vaksin yaitu sebesar Rp49.875.000,00. Urutan kelima adalah biaya vitamin dan obat yaitu sebesar Rp17.100.000,00. Urutan terakhir adalah biaya listrik yaitu sebesar Rp12.000.000,00.

\section{Biaya total produksi}

Biaya total merupakan penjumlahan dari biaya tetap dan biaya tidak tetap (variabel) pada peternakan ayam ras petelur CV Makmur Jaya. Biaya variabel yang dikeluarkan yaitu sebesar Rp5.537.325.000,00. Pada biaya tetap yang dikeluarkan yaitu sebesar Rp2.082.500.000,00. Jadi untuk perhitungan satuan ternak (ST) dari 30.000 populasi pada CV Makmur Jaya adalah sebesar 300,00 ST. Di bawah ini merupakan rincian total dari seluruh biaya produksi yang dikeluarkan oleh perusahaan ayam ras petelur CV Makmur Jaya Lumajang. 
Hasanah et al.

ANIMPRO: Conference of Applied Animal Science Proceeding Series

Tabel 10. Biaya Total

\begin{tabular}{cccc}
\hline Uraian & Jumlah & Satuan Ternak (ST) & 30.000 ekor \\
\hline Biaya variabel & 5.537 .325 .000 & 18.457 .750 & 184.578 \\
Biaya tetap & 2.082 .500 .000 & 6.675 .000 & 69.417 \\
\hline Total & 7.619 .825 .000 & 25.399 .417 & 253.994 \\
\hline
\end{tabular}

Sumber: Data diolah 2020 CV Makmur Jaya Lumajang

\section{Analisis Penerimaan}

Penerimaan adalah jumlah dari nilai uang (rupiah) yang diperhitungkan dari semua produk yang laku terjual dari perusahaan ayam petelur CV Makmur Jaya. Hal ini sesuai dengan pernyataan Mongi (2014) penerimaan merupakan hasil dari perkalian antara jumlah dari produksi yang dihasilkan dengan harga jual, maka dari itu semakin banyak produk yang dihasilkan maka akan semakin besar pula jumlah dari suatu penerimaan yang diperoleh oleh suatu perusahaan ayam ras petelur CV Makmur Jaya. Menurut Saediman (2012) total dari penerimaan harus lebih tinggi dibandingkan dari total biaya. Hal ini dikarenakan total dari penerimaan akan dikurangi dengan biaya total dari suatu perusahaan untuk mendapatkan suatu keuntungan. Jadi pernyataan tersebut dapat disimpulkan yaitu semakin tinggi selisih antara total penerimaan dengan total biaya maka semakin tinggi pula keuntungan yang akan diperoleh oleh perusahaan ayam ras petelur CV Makmur Jaya tersebut.

Penerimaan di peternakan ayam ras petelur CV Makmur Jaya meliputi penjualan telur ayam dan penjualan ayam afkir. Namun pada kedua penjualan tersebut yang paling tinggi adalah penerimaan dari penjualan telur. Hal ini sesuai dengan hasil penelitian Warsito (2010) bahwa penerimaan dari penjualan telur merupakan penerimaan yang paling tertinggi dibandingkan dari penerimaan lainnya seperti pada penjualan ayam afkir maupun penjualan kotoran. Pada peternakan ayam ras petelur CV. Makmur Jaya tidak ada penerimaan melalui penjualan kotoran ayam, karena pada pemilik perusahaan kotoran dibagikan pada petani dan karyawan pada peternakan tersebut. Jadi untuk perhitungan satuan ternak (ST) dari 30.000 populasi pada CV Makmur Jaya adalah sebesar 300,00 ST. Tabel dibawah ini merupakan rincian Analisis Penerimaan pada CV Makmur Jaya Lumajang.

Tabel 11. Analisis Penerimaan

\begin{tabular}{ccccccc}
\hline Uraian & Produksi & Jumlah & $\begin{array}{c}\text { Harga per } \\
\text { Kg (Rp) }\end{array}$ & $\begin{array}{c}\text { Per 12 bulan } \\
(\mathrm{Rp})\end{array}$ & $\begin{array}{c}\text { Satuan } \\
\text { Ternak (ST) }\end{array}$ & $\begin{array}{c}30.000 \\
\text { ekor }\end{array}$ \\
\hline Telur ayam & 8.272 .272 & 521.340 & 17.000 & 8.862 .780 .000 & 29.542 .600 & 295.426 \\
Ayam afkir & 9.500 & 9.500 & 38.000 & 361.000 .000 & 1.203 .333 & 12.033 \\
\hline Total & & & & 9.223 .780 .000 & 30.745 .933 & 307.459 \\
\hline
\end{tabular}

Sumber : Data diolah 2020 CV. Makmur Jaya Lumajang

Tabel di atas merupakan gambaran pada penerimaan yang dihasilkan pada peternakan ayam ras petelur CV. Makmur Jaya. Peneriman yang diperoleh sangat dipengaruhi oleh harga pasar, karena semakin tinggi harga telur dipasar, maka semakin tinggi pula penerimaan yang diperoleh di CV. Makmur Jaya. Pada CV. Makmur Jaya hasil produksi telur ayam sebesar 8.272 .272 butir atau $521.340 \mathrm{~kg}$ dalam setahun sehingga dikalikan dengan harga telur per kilogram sebesar Rp17.000 adalah Rp8.862.780.000,00. Sedangkan ayam afkir sebanyak 9.500 ekor dan dikalikan dengan harga per kilogram sebesar Rp19.000,00 namun pada ayam afkir biasanya beratnya $2 \mathrm{~kg}$ jadi satu ekor ayam afkir diberi harga sebesar Rp38.000,00. Jadi untuk penerimaan ayam afkir sebesar Rp361.000.000. Total dari penerimaan pada CV. Makmur Jaya adalah sebesar Rp9.223.780.000,00 yang merupakan penjumlahan antara total penerimaan pada penjualan telur dan ayam afkir.

\section{Analisis Pendapatan}

Pendapatan adalah sejumlah uang yang didapatkan setelah semua biaya tetap dan biaya variabel tertutupi (Rasyaf, 2003). Hal ini dapat dijelaskan bahwa pada peternakan ayam ras 
Hasanah et al.

ANIMPRO: Conference of Applied Animal Science Proceeding Series

petelur CV Makmur Jaya hasil dari pendapatan tersebut merupakan hasil bersih dari penerimaan penjualan telur dan ayam afkir setelah dikurangi biaya produksi. Pendapatan dalam perusahaan ayam petelur pada CV Makmur Jaya ini sangat diperlukan untuk mengetahui selisih besarnya hasil produksi yang diperoleh dengan besarnya biaya yang dikeluarkan. Hasil pendapatan yang diperoleh adalah sebesar Rp1.603.955.000,00 yang didapatkan dari hasil penerimaan sebesar Rp9.223.780.000,00 dikurangi total biaya sebesar Rp7.619.825.000,00. Pendapatan tersebut bernilai positif, artinya pada perusahaan ayam ras petelur memperoleh keuntungan. Hal ini sesuai pendapat Asnawi (2009), apabila hasil selisih dari penerimaan dan biaya produksi yang dikeluarkan bernilai positif maka dapat disimpulkan bahwa usaha peternakan tersebut memperoleh keuntungan, dan apabila bernilai negatif maka usaha peternakan tersebut mengalami kerugian. Analisis pendapatan ini memiliki fungsi yaitu untuk mengetahui perkembangan usaha pada periode waktu tertentu yang dijalankan oleh suatu peternakan (Tambunan, 2015). Jadi pada peternakan CV. Makmur Jaya, dengan adanya analisis pendapatan ini peternak dapat membuat suatu rencana yang berkaitan dengan pengembangan usaha yang didirikan. Berikut merupakan tabel dari analisis pendapatan secara rinci. Jadi untuk perhitungan satuan ternak (ST) dari 30.000 populasi pada CV. Makmur Jaya adalah sebesar 300,00 ST. Tabel dibawah ini merupakan rincian Analisis Pendapatan pada CV. Makmur Jaya Lumajang.

Tabel 12. Analisis Pendapatan

\begin{tabular}{cccc}
\hline Uraian & Jumlah & Satuan Ternak (ST) & 30.000 ekor \\
\hline Penerimaan & 9.223 .780 .000 & 30.745 .933 & 307,459 \\
Biaya Produksi & 7.619 .825 .000 & 25.399 .417 & 253,994 \\
\hline Total & 1.603 .955 .000 & 5.346 .517 & 53,465 \\
\hline
\end{tabular}

Sumber: Data diolah 2020 CV Makmur Jaya Lumajang

Analisis Penerimaan Atas Biaya (R/C)

Pendapatan dari suatu usaha yang bernilai besar tidak selalu mencerminkan tingkat efisiensi usaha yang tinggi, maka dari itu untuk mengetahui efisiensi usaha yang dijalankan khususnya pada peternakan ayam ras petelur CV. Makmur Jaya dapat digunakan analisis penerimaan atas biaya. Nilai penerimaan atas biaya $(\mathrm{R} / \mathrm{C})$ rasio adalah perbandingan antara penerimaan yang diperoleh peternakan ayam ras petelur CV Makmur Jaya yaitu sebesar Rp9.223.780.000,00 dengan biaya total yaitu sebesar Rp7.619.825.000,00. Berdasarkan penerimaan dan biaya yang dikeluarkan, nilai penerimaan atas biaya yang diperoleh pada peternakan ayam ras petelur CV. Makmur Jaya adalah sebesar 1,210. Angka penerimaan atas biaya sebesar 1,210 menunjukkan bahwa peternakan ayam ras petelur CV. Makmur Jaya memperoleh untung. Hal ini sesuai pendapat dari Soepranianondo (2013), jika nilai dari R/C lebih dari 1 maka usaha tersebut menguntungkan dan layak untuk dijalankan. Perhitungan hasil analisis penerimaan atas biaya $(\mathrm{R} / \mathrm{C})$ rasio terdapat pada tabel dibawah ini. Jadi untuk perhitungan Satuan Ternak (ST) dari 30.000 populasi pada CV Makmur Jaya adalah sebesar 300,00 ST. Tabel di bawah ini adalah rincian Analisi Penerimaan Atas pada CV. Makmur Jaya Lumajang.

Tabel 13. Analisis Penerimaan Atas Biaya (R/C)

\begin{tabular}{cccc}
\hline Uraian & Jumlah & Satuan Ternak (ST) & 30.000 ekor \\
\hline Total penerimaan & 9.223 .780 .000 & 30.745 .933 & 307.459 \\
Biaya total & 7.619 .825 .000 & 25.399 .417 & 253.994 \\
\hline Total & 1,210 & 0,004 & 0,00004 \\
\hline
\end{tabular}

Sumber: Data diolah 2020 CV. Makmur Jaya Lumajang

Analisis Break Even Point (BEP)

Analisis break even point (BEP) merupakan sarana untuk menentukan kapasitas dari suatu produksi yang harus dicapai oleh suatu perusahaan agar memperoleh kentungan (Nasution, 2006), jadi analisis break even point (BEP) ini dimaksudkan untuk mengetahui titik impas dari 
suatu usaha yang dijalankan. Pada perusahaan peternakan ayam ras petelur CV. Makmur Jaya dengan menggunakan analisis BEP atau biasa disebut titik impas dapat memberikan informasi mengenai berapa jumlah volume penjualan dimana peternakan tersebut berada pada kondisi tidak memperoleh laba tetapi juga tidak rugi. BEP dibagi dua yaitu BEP harga dan BEP produksi. Analisis Break Even Point (BEP) pada peternakan ayam ras petelur CV. Makmur Jaya dapat dilihat pada tabel dibawah ini.

\section{BEP Harga}

Berdasarkan hasil analisis pada tabel diatas, dapat diketahui bahwa BEP harga adalah hasil bagi antara total biaya yang dikeluarkan dengan total telur ayam yang diproduksi. BEP harga adalah besarnya harga minimal per unit barang yang ditetapkan oleh peternakan ayam ras petelur CV Makmur Jaya. Pada peternakan ayam ras petelur CV Makmur Jaya untuk memperoleh BEP harga yaitu hasil bagi antara total biaya produksi sebesar Rp7.619.825.000 dengan total produksi telur sebanyak $521.340 \mathrm{~kg}$. Nilai BEP harga yang diperoleh pada peternakan ayam ras petelur CV Makmur Jaya sebesar Rp14.615,845705. Jadi untuk perhitungan satuan ternak (ST) dari 30.000 populasi pada CV Makmur Jaya adalah sebesar 300,00 ST.

Tabel 14. BEP Harga

\begin{tabular}{cccc}
\hline Uraian & Jumlah & Satuan Ternak (ST) & 30.000 ekor \\
\hline Total Biaya Produksi & 7.619 .825 .000 & 25.399 .417 & 253.994 \\
Total Produksi & 521.340 & 1.738 & 17,378 \\
\hline Total & $14.615,845$ & 48,719 & 0,487 \\
\hline
\end{tabular}

Sumber: Data diolah 2020 CV Makmur Jaya Lumajang

\section{BEP Produksi}

Berdasarkan hasil analisis tabel diatas, dapat diketahui bahwa BEP produksi adalah hasil bagi antara total biaya yang dikeluarkan dengan harga jual telur ayam. Pada peternakan ayam ras petelur CV Makmur Jaya untuk memperoleh nilai BEP produksi yaitu hasil bagi antara total biaya produksi sebesar Rp7.619.825.000,00 dengan harga penjualan yaitu sebesar Rp17.000,00. Nilai BEP produksi yang diperoleh peternakan ayam ras petelur CV Makmur Jaya sebesar $448.225 \mathrm{~kg}$. jadi untuk perhitungan satuan ternak (ST) dari 30.000 populasi pada CV Makmur Jaya adalah sebesar 300,00 ST.

Tabel 15. BEP Produksi

\begin{tabular}{cccc}
\hline Uraian & Jumlah & Satuan Ternak (ST) & 30.000 ekor \\
\hline Total biaya produksi & 7.619 .825 .000 & 25.399 .417 & 253.994 \\
Harga penjualan & 17.000 & 56,6667 & 0,567 \\
\hline Total & 448.225 & 1.494 & 14,941 \\
\hline
\end{tabular}

Sumber: Data diolah 2020 CV Makmur Jaya Lumajang

\section{KESIMPULAN}

Kesimpulan yang dapat diambil dari hasil penjelasan analisis usaha pada CV Makmur Jaya diantaranya, yaitu total biaya produksi yang dikeluarkan adalah sebesar Rp7.619.825.000,00; total penerimaan yang diperoleh adalah sebesar Rp9.223.780.000,00; total pendapatan yang diperoleh CV Makmur Jaya sebesar Rp1.603.955.000,00. Analisis R/C di CV. Makmur Jaya menunjukkan angka 1,210. Analisis BEP harga dan BEP produksi diperoleh hasil Rp14.615,845 dan $448.225 \mathrm{~kg}$ sehingga dapat disimpulkan bahwa usaha peternakan ayam ras petelur CV Makmur Jaya layak untuk dijalankan. 
Amsyah, Zulkifli. 2003. Manajemen Kearsipan. Jakarta: PT. Gramedia Pustaka Utama.

Arifin, A. 2004. Membaca Saham. Yogyakarta: Andi Yogyakarta.

Asnawi. 2009. Metodologi Riset Manajemen Pemasaran. Malang: UIN Malang Press.

Bachtiar, Ibrahim. 2009. Rencana dan estimate Real of Cost. Jakarta: Bumi Aksara.

Direktorat Jenderal Peternakan dan Kesehatan Hewan. 2015. Daftar Populasi, Konsumsi, dan Produksi Ternak. Jakarta: Direktorat Jenderal Peternakan dan Kesehatan Hewan.

Candra, S., H. D. Utami, dan B. Hartono. 2012. Analisis Ekonomi Usaha Ayam Petelur CV. Santoso Farm. Malang: Universitas Brawijaya.

Fadillah, R. dan Polana, A. 2011. Mengatasi 71 Penyakit Pada Ayam. Jakarta: Agro Media Pustaka.

Himawati, D. 2006. Analisis Resiko Finansial Usaha Peternakan Ayam Pedaging pada Peternakan Plasma Kemitraan KUD "Sari Bumi" di Kecamatan Bululawang Kabupaten Malang. Malang: Fakultas Peternakan Universitas Brawijaya.

Ibrahim, H.M.Y. 2003. Studi Kelayakan Bisnis. Jakarta: Rineka Cipta.

Mongi, H. 2014. Analisis Profitabilitas Usaha Peternakan Ayam Petelur Bina Ternak Mandiri di Kelurahan Mapane Kecamatan Poso Pesisir. Sulawesi: Jurnal Agro Peternakan.

Mulyadi. 2001. Akuntansi Manajemen. Jakarta: Edisi Ketiga Salemba Empat.

Munawir, S. 2002. Analisis Informasi Keuangan. Yogyakarta: Liberty Yogya.

Nasution, Arman Hakim. 2006. Manajemen Industri. Yogyakarta: Andi.

Rasyaf. 2003. Memasarkan Hasil Peternakan. Jakarta: Penebar Swadaya.

Rasyaf. 2005. Beternak Ayam Petelur. Jakarta: Penebar Swadaya.

Rahardi, F. dan Hartono. 2003. Agribisnis. Jakarta: Penebar Swadaya.

Saediman. 2012. Pengaruh Skala Usaha Terhadap Pendapatan Peternak Ayam Ras Petelur di Kecamatan Maritengngae Kabupaten Sidrap. Makassar: Fakultas Peternakan Universitas Hasanuddin.

Simanungkalit, Rutkaya. 2008. Inventaris Makanan Khas Toba dan Strategis Pengembangannya. Medan: Fakultas Pertanian Universitas Sumatera Utara.

Soekartawi. 2003. Teori Ekonomi Produksi. Jakarta: PT. Raja Grafindo Persada.

Soepranianondo, K., R. Sidik, D.S. Nazar, S. Hidanah, Prasisto dan S.H. Warsito. 2013. Buku Ajar Kewirausahaan. Surabaya: Pusat Penerbitan dan Percetakan Unair.

Suprapti, L. 2002. Pengawetan Telur. Yogyakarta: Kanisus.

Tambunan, A. 2015. Analisis Kelayakan Usaha Ayam Petelur. Bogor: Fakultas Ekonomi dan Manajemen Institut Pertanian Bogor.

Warsito, S. H. 2010. Analisis Finansial, Resiko dan Sensitivitas Usaha Peternakan Ayam Petelur. Malang: Universitas Brawijaya. 